\title{
ANALISIS DAN IMPLEMENTASI MODEL PERAMALAN BERBASIS ALGORITMA MOVING AVARAGE UNTUK NILAI TUKAR RUPIAH TERHADAP DOLAR
}

\author{
First Ryan \\ Fakultas Ilmu Komputer, Program Studi Teknik Informatika \\ Universitas Dian Nuswantoro Semarang \\ Email: firstryan@gmail.com \\ Wijanarto \\ Fakultas Ilmu Komputer, Program Studi Teknik Informatika \\ Universitas Dian Nuswantoro Semarang \\ Email: wijanarto.udinus@gmail.com
}

\begin{abstract}
ABSTRAK
Salah satu faktor yang mempengaruhi kuatnya ekonomi suatu negara adalah nilai tukar mata uang (kurs). Pada beberapa kasus yang terjadi di negara maju seperti Eropa atau Amerika, nilai tukar mata uang merupakan bagian yang sangat vital, hingga berpengaruh menghambat perdagangan internasional. Tidak terkecuali di Indonesia, yang menganut sistem pasar penuh/bebas (free floating system) dimana nilai tukar rupiah terhadap mata uang asing khususnya dolar (USD) ditentukan oleh pasar mekanisme global. Kebijakan pemerintah dalam menguatkan nilai tukar rupiah perlu dilakukan mengingat dalam 10 tahun terakhir mengalami kemunduran dari titik 9.087 di tahun 2010 menuju titik 11.900 di awal tahun 2015, sehingga kedepan perlu dilakukan perencanaan fiskal yang fokus, teliti dan tepat. Paper ini berusaha mengimplementasikan model regresi linier berbasis algoritma moving average yang didasarkan pada variasi musiman (seasonal movement) yang didekomposisikan untuk nilai tukar rupiah terhadap dolar dalam bentuk aplikasi. Analisis dan visualisasi model dilakukan dengan bahasa pemrograman R, sementara aplikasi dibangun berbasis web dengan php. Data historis diperoleh dari situs Bank Indonesia dalam kurun waktu 2011 - 2017. Berdasarkan analisa dan hasil penelitian terhadap model yang diimplementasikan, didapatkan pengukuran tingkat akurasi dengan RMSE, MAE dan MAPE diperoleh masing-masing sebesar 114.0173, 57.69148 dan 0.64766, dari ketiga hasil evaluasi menunjukan bahwa mempunyai sedikit selisih antara data asli dengan hasil peramalannya. Sementara aplikasi dapat berjalan sempurna dan menghasilkan komputasi peramalan yang sesuai dengan model yang dipilih.
\end{abstract}

Kata kunci: analisis, peramalan, model, moving average.

\begin{abstract}
One of the factors affecting the strength of the country's economy is the exchange rate (exchange rate). In some cases in developed countries like Europe or the United States, currency exchange rates are a vital part of the world, which in turn has an effect on hampering international trade. No exception in Indonesia, which embraces a free / floating system where the rupiah exchange rate against foreign currencies especially dollars (USD) is determined by global market mechanism. Government policy in strengthening rupiah exchange rate needs to be done considering that in the last 10 years decline from point 9.087 in 2010 to the point 11,900 at the beginning of 2015, so the future needs to be fiscal planning that is focused, thorough and accurate. This paper attempts to implement a linear regression-based regression model based on the seasonal movement decomposed for the rupiah exchange rate against the dollar in the form of an application. Analysis and visualiasi model is done with $R$ programming language, while the application built web-based with php. Historical data was obtained from Bank Indonesia website during 2011 - 2017. Based on the analysis and the results of the research on the model implemented, the results obtained by measurement with RMSE, MAE and MAPE obtained respectively of 114.0173, 57.69148 and 0.64766, from the three evaluation results show have little difference between the original data with the results of forecasting. While the application can run perfectly and produce computational forecasting in accordance with the selected model.
\end{abstract}

Keywords: analysis, forecasting, model, moving average. 


\section{PENDAHULUAN}

Dalam tatanan sebuah negara sektor ekonomi merupakan salah satu hal terpenting. Dan salah satu faktor yang mempengaruhi kuatnya ekonomi suatau negara adalah nilai tukar mata uang (kurs). Terlebih di era global ini pertukaran mata uang antar negara makin sering terjadi. Baik dikalangan pemerintahan hingga masyarakat sekarang sudah bertransaksi dan bertukar mata uang antar negara. Pada beberapa kasus yang terjadi di negara maju seperti di wilayah Eropa atau Amerika, nilai tukar mata uang merupakan bagian yang sangat vital. Bahkan pengaruh resiko nilai tukar mata uang akan mempengaruhi dan menghambat perdagangan internasional [1,2]. Oleh karena itu negara- negara yang tergabung dalam Uni-Eropa membentuk kesepakatan untuk menyatukan nilai tukar mata uang dengan negara Uni- Eropa lainya sehingga terbitlah mata uang euro. Hal ini merupakan langkah dari Uni- Eropa untuk mengurangi resiko yang disebabkan nilai tukar mata uang. Indonesia sendiri menganut sistem pasar penuh/bebas (free floating system) dimana nilai tukar rupiah terhadap mata uang asing khususnya dolar (USD) ditentukan oleh pasar mekanisme global. Kebijakan pemerintah dalam menguatkan nilai tukar rupiah salah satunya dengan mendorong sektor ekspor dalam negeri. Salah satunya menaikan harga minyak (BBM) untuk harga jual ke luar negeri dan kebijakan dengan menaikan BI Rate dalam upaya meningkatkan ketahanan fiskal [3].

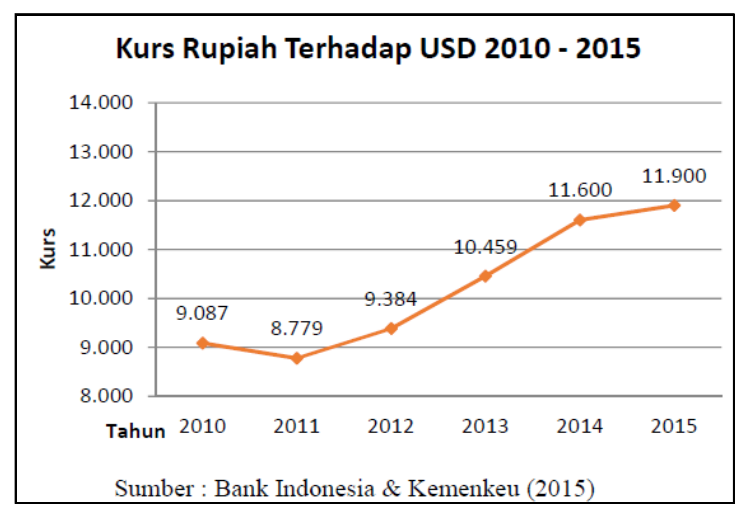

Gambar 1. Kurs Rupiah 2010-2015

Berdasarkan data dari Bank Indonesia nilai tukar rupiah terus melemah dari tahun 2010 dari poin 9.087 menuju poin 11.900 di awal tahun 2015 seperti ditunjukan pada gambar 1. Dan pada tahun 2015 akhir nilai tukar rupiah sempat mencapai angka 14.000 yang merupakan nilai terburuk dalam kurun waktu 10 tahun terakhir. Beberapa penelitian nterkait dengan tema diatas sudah banyak dilakukan, Zhang dan Berardi [4] membahas tentang penggabungan algoritma neural network untuk peningkatan kinerja dalam peramalan time series.

Hasil penelitian juga menunjukkan bahwa ensambel saraf berdasarkan partisi yang berbeda dari data lebih efektif daripada yang dikembangkan dengan data pelatihan penuh diluar sampel peramalan. Dalam bagian lainnya, Emam[5] memaparkan hasil penelitian empiris yang cenderung mengkonfirmasi penerapan model jaringan saraf ke peramalan pasar kurs valuta asing. Syaraf tiruan jaringan telah terbukti efisien dan menguntungkan dalam peramalan. Keuangan time series khususnya, yang menggunakan topologi ANN optimal yang menunjukan hasil yang baik dalam hasil premalan. Hasil predikasi mingguan menunjukkan hasil yang baik dan lebih sedikit kegagalan karena memiliki banyak sampel data. Sedangkan peramalan bulanan lebih kurang akurat karena kurangnya sampel data. Richard, Bermudez dan Honeine [6] membahas seberapa cocok algoritma time series ini terhadap data kernel yang telah dikumpulkan kedalam aplikasi online. Sehingga aplikasi tersebut bisa menjadi pembanding cocok tidaknya algoritma time series dimasukan kedalam aplikasi online. Penelitian nilai tukar rupiah terhadap dolar Amerika oleh Wahyudi [7] menyebutkan bahwa meramal nilai tukar mata uang khususnya kurs dolar merupakan salah satu kunci strategis dalam dunia bisnis internasional. Dan pada proses dengan membandingkan data riil (nyata) dengan hasil simulasi menggunakan jaringan syaraf tiruan. Dalam penelitian lainnya $[8,9,10]$ memaparkan, terdapat tiga jenis kurs yaitu, kurs jual, kurs beli, dan kurs tengah. Kurs juga dibutuhkan untuk menentukan keputusan penganggaran modal, keputusan investasi jangka pendek, penilaian laba dan keputusan pembiayaan jangka panjang $[11,12,13,14]$. Paper ini akan mengimplementasikan model regresi linier, dengan basis algoritma center moving average, karena kesederhanaanya tetapi mampu melakukan peramalan dengan bagus. 


\section{METODOLOGI PENELITIAN}

Metode yang dipakai dalam paper ini dibagi menjadi 2 bagian besar. Pertama, analisa dan visualisasi model, untuk mendapatkan gambaran mengenai data yang akan diteliti, analisa akan dilakukan dengan cara melihat data yang diterapkan pada model, dimana model yang dipakai adalah menggunakan library forecast, quantmod, tseries dan zoo pada bahasa pemrograman $\mathrm{R}[15,16,17,18]$, begitu juga visualisasi data dalam bentuk grafiknya. Metode ini dipakai untuk menguji model apakah sudah tepat atau belum guna diimplementasikan menjadi suatu aplikasi. Kedua, membangun aplikasi berbasis web sebagai implementasi model yang dipilih, aplikasi dibangun berbasis web yang ditulis dengan bahasa pemrograman server $p h p$, sementara server basisdata dipakai adalah mysql.

Aplikasi dirancang berbasis teknik RAD (Rapid Application Development) [19] dengan memodelkan secara objek orientied dan implementasi bahasa menggunakan server side web programming. Secara umum metode yang akan dipakai dalam penelitian ini seperti tampak pada gambar 2 dibawah ini :

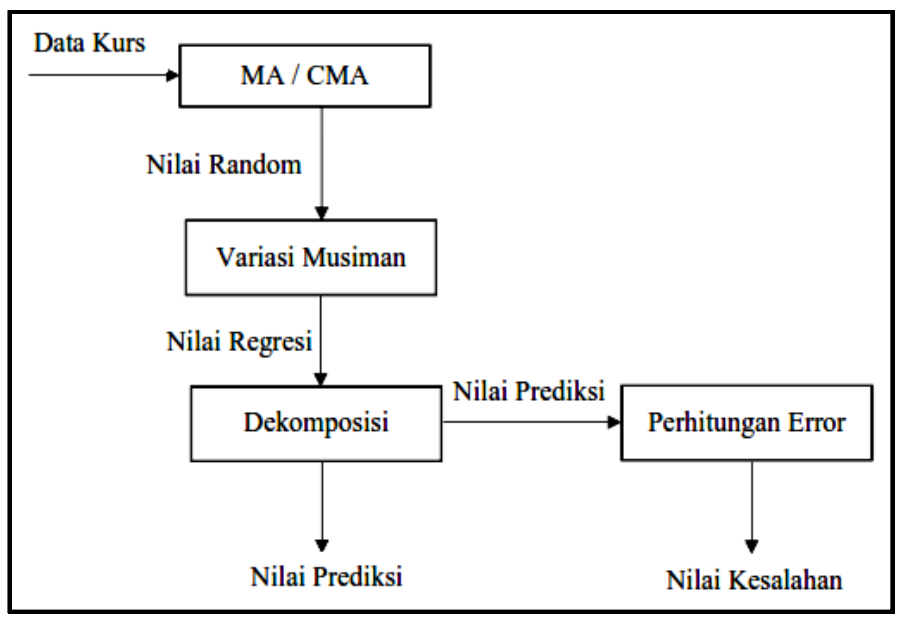

Gambar 2. Metodelogi Penelitian

Data kurs akan dilakukan analisis dengan model yang dipilih (MA dan CMA), steelah model di buat, langkah selanjutnya adalah meberi nilai random untuk menentukan variasi musiman untuk mendapatkan nilai regresinya, setelah itu akan dilakukan dekomposisi untuk menghasilkan nilai peramalan. Nilai peramalan yang di hasilkan akan dievaluasi tingkat perbedaan antara data aktual dengan data hasil peramalan dengan MAE, MAPE dan RMSE.

\subsection{Analisa Data}

Metode yang pertama akan dilakukan dalam penelitian ini adalah melakukan analisa terhadap model dan algoritma yang dipilih untuk melakukan peramalan nilai tukar atau kurs dollar terhadap rupiah dengan menggunakan bahasa pemrograman R, berikut langkah-langkah yang akan dilakukan sesuai model pada gambar 2 diatas yang terdiri dari :
a. Analisa pola data awal
b. Konversi data time series
c. Periksa stasionary data
d. Seasonal differencing
e. Menghapus variasi musiman
f. Peramalan
g. Interpretasi Model Peramalan
h. Validasi dengan Prediction error
i. Evaluasi akurasi peramalan 


\subsection{Perancangan Arsitektur Aplikasi}

Aplikasi yang akan dibuat, akan dirancang dan dibangun berdasarkan pendekatan pengembangan system dalam hal ini teknik RAD, yaitu mulai analisa kebutuhan system, disain dan implementasi. Gambar 3 menunjukan arsitektur umum aplikasi.

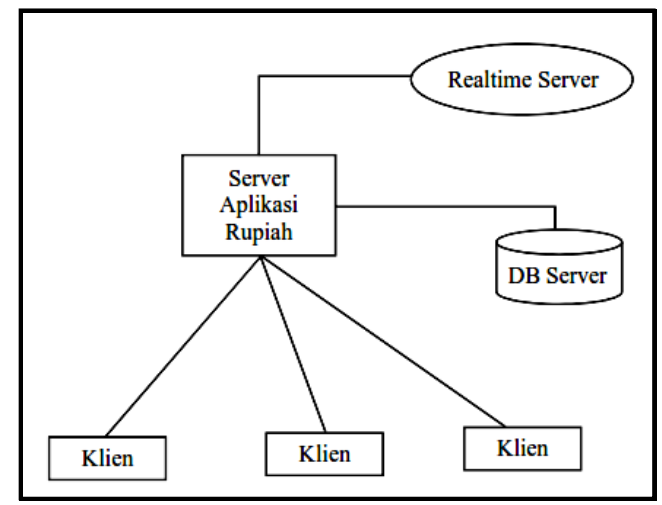

(a)

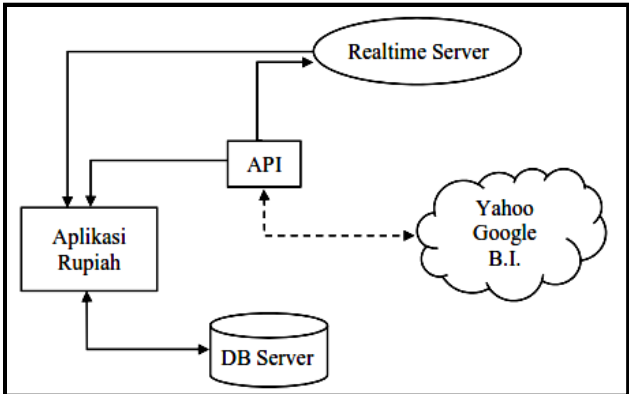

(b)

Gambar 3. Arsitektur Umum (a) dan Realtime Aplikasi (b)

Aplikasi server (php) bertindak sebagai aplikasi utama yang akan melayani klien yang menggunakan aplikasi, dimana saat menjalankan permintan klien, aplikasi akan menggunakan data pada RDBMS (mysql) melalui service web yang dipakai (apache). Sementara pada system realtime Aplikasi menggunakan API untuk mengakses data keuangan dari sumber (yahoo, google dan BI) untuk disimpan ke dalam basisdata, seperti dalam gambar 4 arsitektur database aplikasi di bawah ini

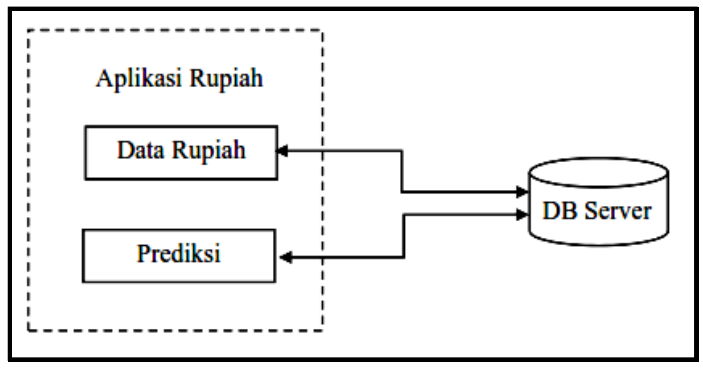

Gambar 4. Arsitektur DBMS

Terdapat 2 database yang akan mengelola data aplikasi yaitu data nominal dari sumber (yahoo, google dan BI) yang disimpan dalam database rupiah, serta data hasil perhitungan peramalan dalam database peramalan.

\subsubsection{Analisa Kebutuhan}

Hasil analisa ini akan menentukan kebutuhan aplikasi yang akan dibangun, mulai dari kebutuhan software (RDBMS, web server, browser, API, bahasa pemrograman, bahasa pemodelan), Hardware (kebutuhan minimum untuk menjalankan aplikasi). RDBMS yang di pilih adalah mysql server, webservicenya adalah open source apache dengan bahasa server php yang di paket mengggunakan xamp, API yang dipakai untuk Browser dapat menggunakan ie, firefox ataupun chrome, pemodelan menggunakan visual paradigm. Sementara kebutuhan hardware adalah minimal prosesor sekelas dual core, dengan RAM 4 GB, HDD 250 GB dipasang OS Window 7.

\subsubsection{Desain}

Untuk perancangan aplikasi akan dibuat model object oriented dengan UML, mulai dari disain use case, state diagram, sequence diagram hingga class diagram. 
a. Use Case

Usecase diagram adalah gambaran fungsionalitas dari suatu system, sehingga pengguna system paham dan mengerti mengenai kegunaan system yang akan dibangun. Dalam disain use case ini aplikasi utama seperti tampak pada gambar 5 dibawah ini,

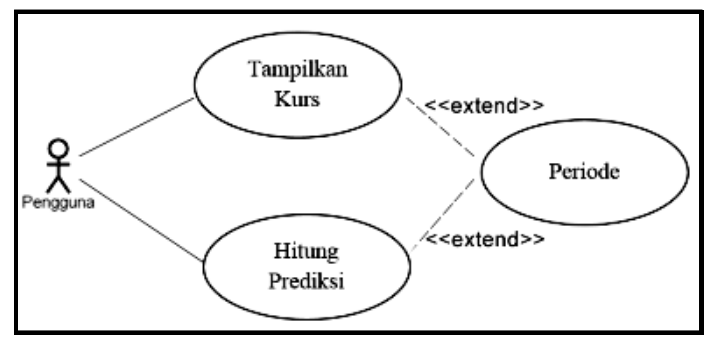

Gambar 5. Use Case

User (pengguna) dapat memilih 2 menu yaitu melakukan peramalan dan menampilkan nilai kurs, dalam periode tertentu.

b. State Diagram

Diagram ini menggambarkan keadaan objek pada suatu waktu didalam sistem. Diagram ini juga menunjukan bagaimana suatu objek beroperasi. Berikut adalah state diagram untuk aktifitas proses menampilkan grafik kurs dan perhitungan peramalan kurs rupiah seperti pada gambar6 dibawah ini.

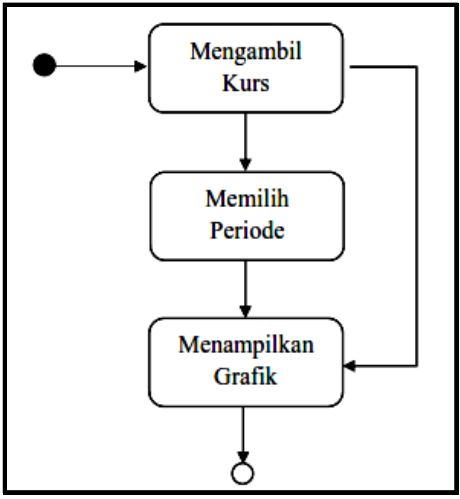

(a)

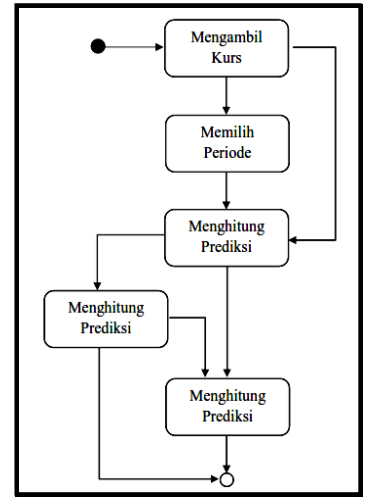

(b)

Gambar 6. State Diagram (a). Grafik Kurs (b) Komputasi Peramalan

c. Sequence Diagram

Sequence diagram adalah suatu diagram yang memberikan gambaran tentang interaksi antar obyek yang mengindikasikan komunikasi diantara obyek-obyek tersebut. Berikut gambaran dari sequence diagram dalam penelitian ini seperti pada gambar 7 dibawah ini.

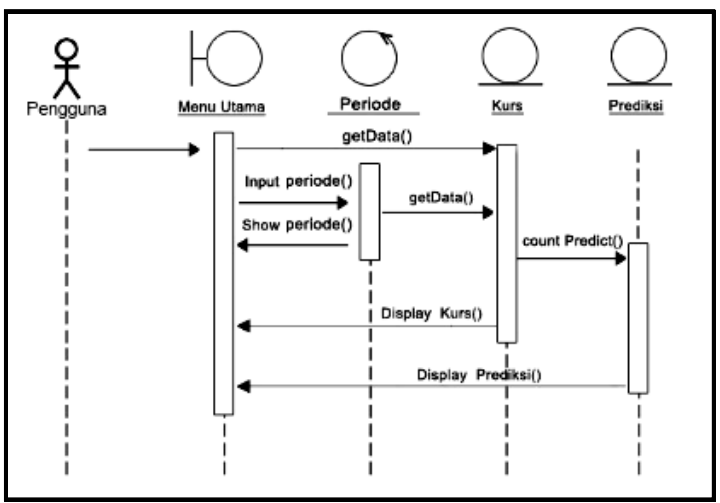

Gambar 7. Sequence Diagram Aplikasi 
Sequence diagram dimulai dari posisi awal dimana pengguna mulai menggunakan system yang dibangun. Setelah itu melewati beberapa proses class dimana terdapat proses input atau output dan bagaimana proses tersebut kembali ke posisi sebelumnya.

d. Class Diagram

Class diagram adalah model statis yang menggambarkan struktur dan deskripsi class serta hubungannya antara class. Dalam penelitian ini class diagram utama terdiri dari class user, Peramalan, Kurs dan Akurasi, seperti pada gambar 8 berikut,

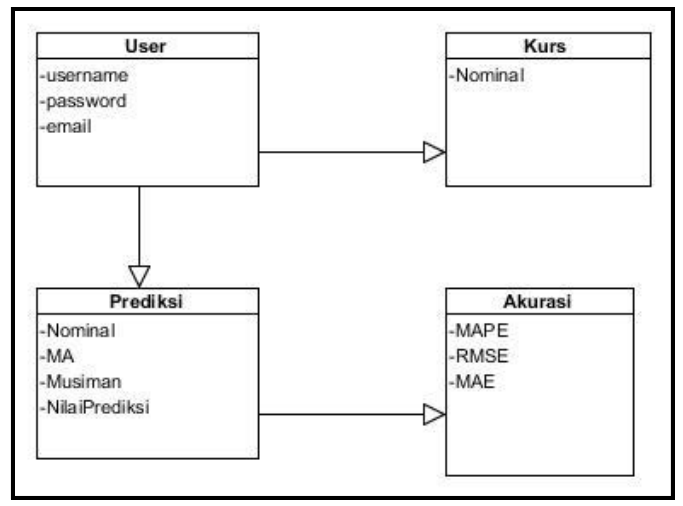

Gambar 8. Class Diagram

Class User berisi atribut utama nama user, password dan email yang dipakai sebagai data dasar pengguna aplikasi, class Kurs akan menyimpan data nominal kurs yang diambil dari sumber data, class Prediksi akan menyimpan komputasi mulai dari data nominal, hasil perhitungan MA/CMA, data musiman, nilai regresi dan peramalan, class Akurasi menyimpan data hasil perhitungan akurasi dari data actual dan data peramalan.

\subsubsection{Notasi Algoritmik Prediksi Nilai Rupiah}

Berikut disajikan notasi algoritmik yang akan diimplementeasikan dalam aplikasi peramalan nilai rupiah terhadap dolar, yang menjadi inti aplikasi dalam class Prediksi, yaitu perhitungan prediksi dan akurasi.

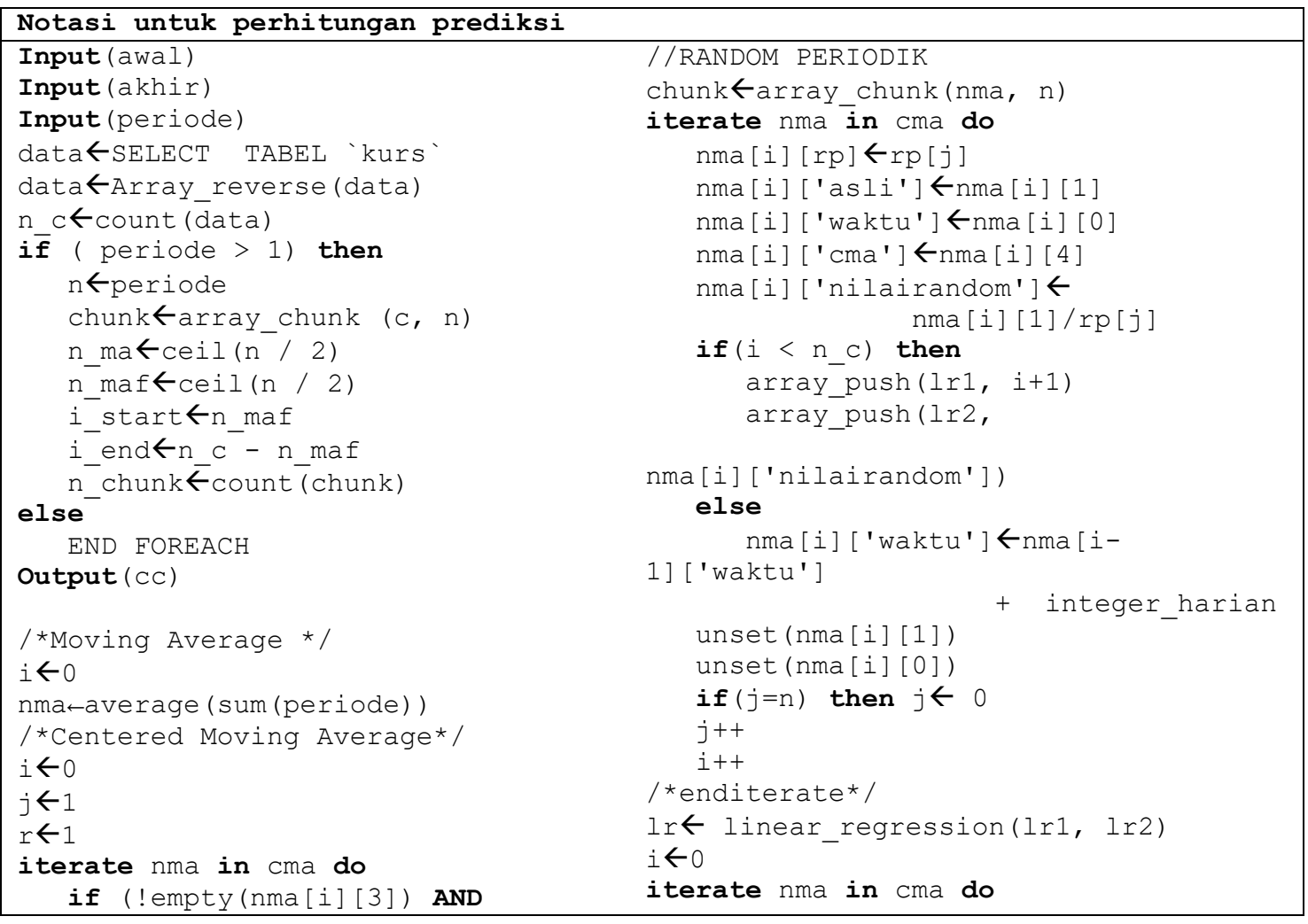




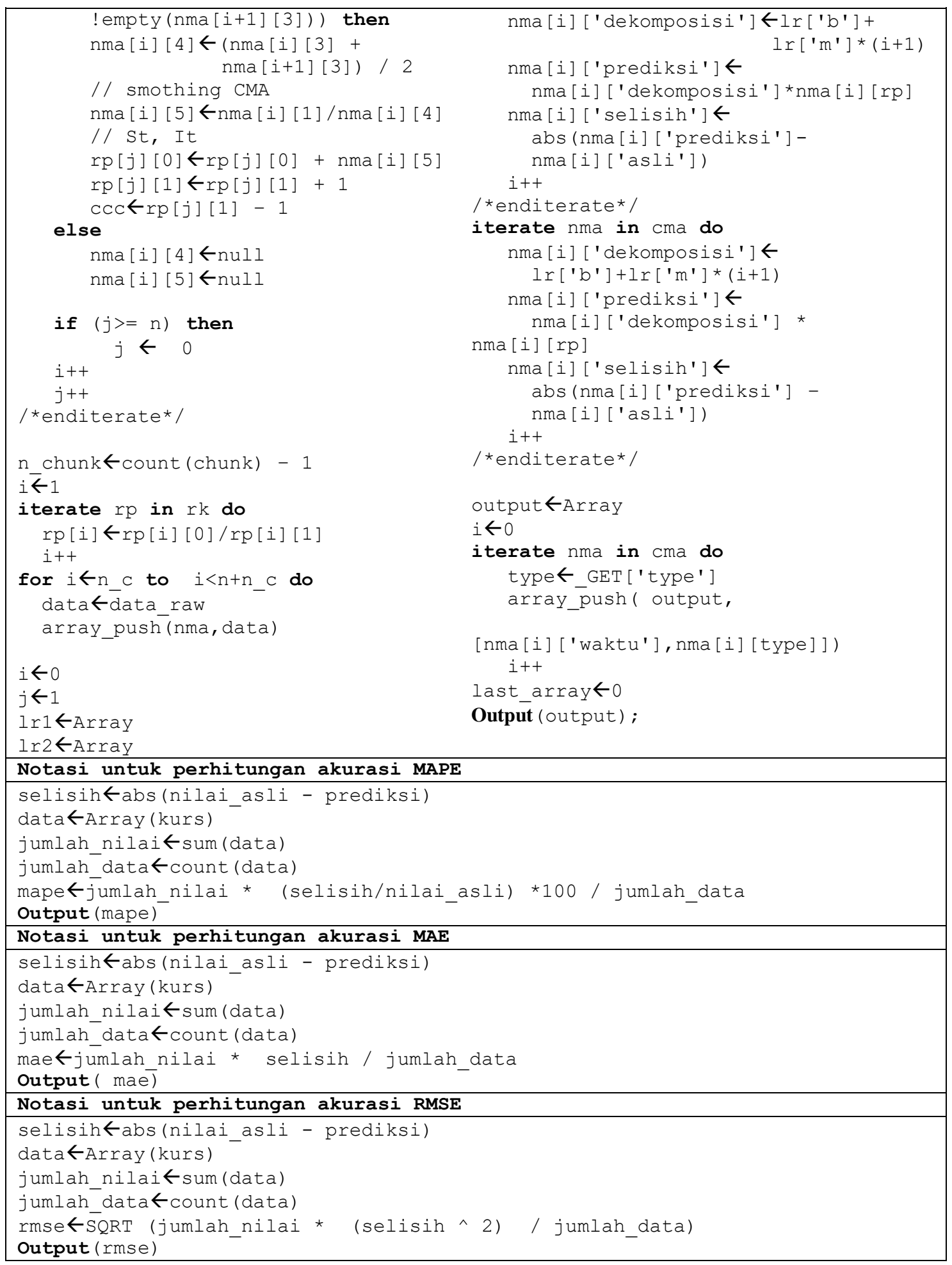

\section{HASIL DAN PEMBAHASAN}

\subsection{Analisa Dan Visualisasi Model Yang Di Pilih}

Tahap pertama dalam serangkaian langkah analisa dan visualisasi model adalah melihat sebaran data awal nilai tukar dollar terhadap rupiah (data harian diperoleh dari secara online dari yahoo finance dengan libraray quantmod) mulai dari Januari 2010 hingga Januari 2018, berikut potongan data yang dapat disajikan dalam table 1 dibawah ini. 


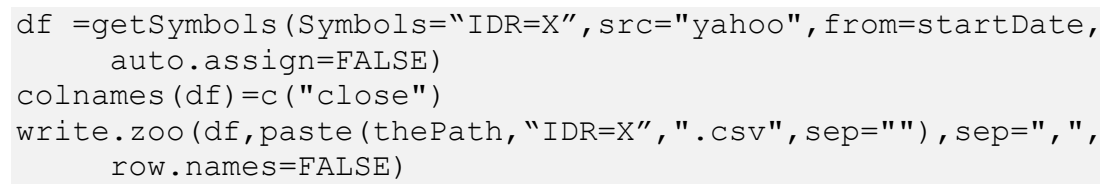

Tabel 1. Data historis kurs rupiah terhadap dollar Januari 2010-2018

\begin{tabular}{ccccllc}
\hline "Index" & "open" & "high" & "low" & "close" & "volume" & "adj." \\
\hline $2010-01-01$ & 9427 & 9427 & 9378 & 9386 & 0 & 9386 \\
$2010-01-04$ & 9386 & 9470 & 9240 & 9364 & 0 & 9364 \\
$2010-01-05$ & 9363 & 9383 & 9200 & 9305 & 0 & 9305 \\
$2010-01-06$ & 9304 & 9355 & 9153 & 9218 & 0 & 9218 \\
$\ldots$ & $\ldots$ & $\ldots$ & $\ldots$ & $\ldots$ & & $\ldots$ \\
$2018-01-01$ & 13562 & 13568 & 13477 & 13542 & 0 & $\ldots$ \\
$2018-01-02$ & 13556 & 13557 & 13467 & 13550 & 0 & 13542 \\
$2018-01-03$ & 13496 & 13506 & 13422 & 13496 & 0 & 13550 \\
$2018-01-04$ & 13472 & 13478 & 13405 & 13468 & 0 & 13496 \\
$2018-01-05$ & 13414 & 13427 & 13384 & 13415 & 0 & 13415 \\
\hline
\end{tabular}

Dengan melakukan ploting terhadap data tersebut diperoleh grafik seperti tersaji pada gambar 9 dibawah ini sebagai berikut,

plot(df,main="Kurs Rupiah Terhadap USD 2010-2018", xlab="Tanggal", ylab="Jual", type="l")

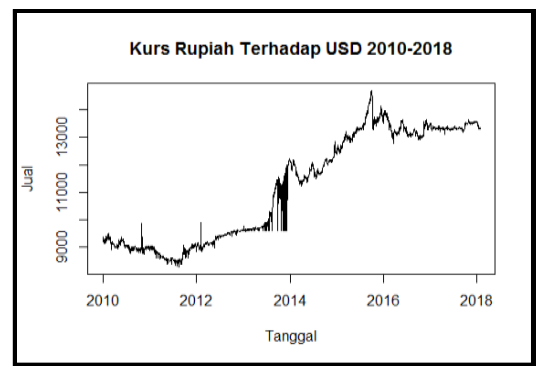

Gambar 9. Grafik Nilai Kurs Rupiah Terhadap Dolar 2010 - 2018

Dari gambar 9 diatas jelas terlihat adanya trend yang cenderung naik dari tahun ke tahun, tetapi tidak menunjukan adanya variasi musiman, juga data nampak terdapat noise (irregular remainder), sehingga perlu didekomposisi supaya mudah untuk diramalkan. Selanjutnya kita perlu membuat data harian time series mulai tahun 2010-2018 untuk dapat meramalkan nilai kurs (jual),

df. ts $<-t s(d f \$ J u a l$, frequency $=365$, start=c $(2010$, as . numeric (format $(d f[, 1]$,

"\%j"))), end = c (2018, as.numeric $($ format $(\mathrm{df}[, 1], " \% j "))))$

Hasil ploting seperti terlihat pada gambar 10 dibawah ini, dimana data tidak stasioner, terlihat dari nilai mean tidak constant, yang menyebabkan komponen trend tak terisi, variance fluktuatif, sementara variasi musiman tidak terlihat, sehingga terlihat seperti random white noise.

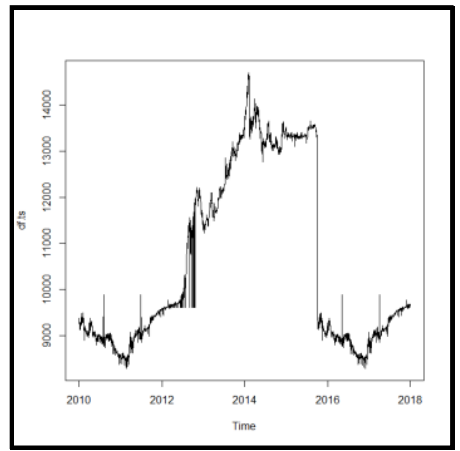

Gambar 10. Grafik Time Series Kurs Rupiah Terhadap Dolar 2010 - 2018 
Dengan melakukan test terhadap data time series diatas kita akan pastikan apakah data sebaran data diatas stasioner atau tidak dengan menggunakan Augmented Dickey-Fuller Test (ADF Test) dan Kwiatkowski-Phillips-Schmidt-Shin (KPSS) test, dengan memanfaatkan library tseries.

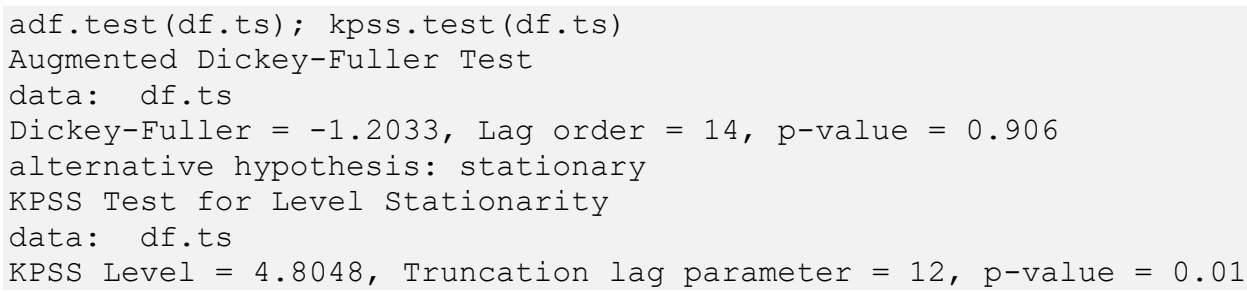

Terlihat hasil ADF memberi nilai p-value 0.906 yang berarti hipotesa nul ditolak jadi data tidak statsioner, begitu juga dengan KPSS, kebalikan dari ADF, nilai p-value semakin kecil menunjukan data tidak stasioner, sehingga perlu distasionerkan untuk mendapatkan variasi musiman dengan library forecast.

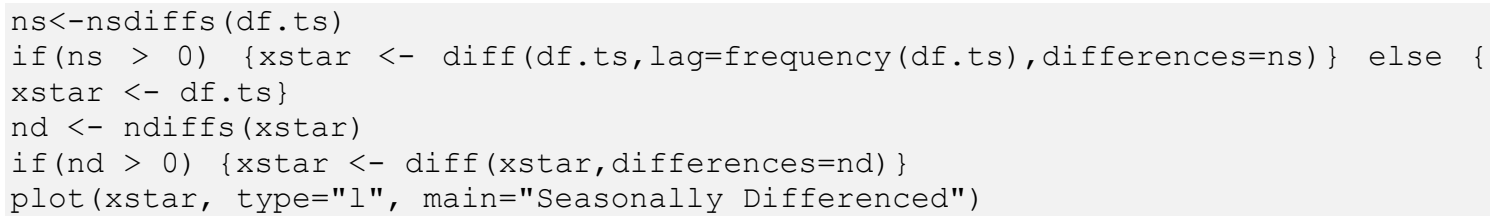

Pertama dihitung jumlah perbedaan data time series yang diperlukan $(n s)$, jika hasilnya lebih dari 0 maka lakukan differensiasi dan jika hasilnya masih belum lebih besar dari 0 lakukan diferensiasi lagi, setelah memenuhi lihat grafik sebaran datanya seperti disajikan pada gambar 11 dibawah ini.

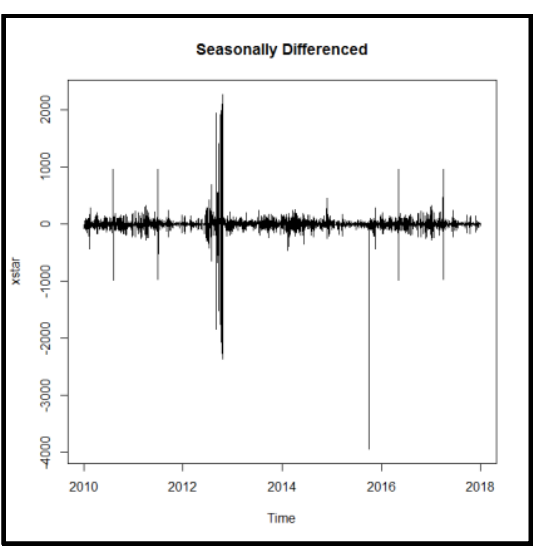

\section{Gambar 11. Grafik Time Series Kurs Rupiah Terhadap Dolar 2010 - 2018}

Langkah selanjutnya adalah menghapus variasi musiman jika ada, penting untuk mengetahui tingkat fluktuasi nilai tukar yang dikaitkan dengan waktu atau musim (season) tertentu dalam tahun tertentu. Musiman atau Seasonality dalam time series dapat mempengaruhi nilai yang diramalkan (diprediksikan) dan biasanya merupakan praktik yang baik untuk menghilangkan variasi dari data time series. Untuk menghilangkan variasi musiman, time series harus didekonstruksi ke komponennya dengan menggunakan fungsi decompose() yang membagi data time series menjadi komponen \$musiman/seasonal dan \$trend.

df.tscompose <-decompose (df.ts)

plot (df.tscompose)

df.tsSeasonalAdjusted <- df.ts -df.tsCompose\$seasonal

dev.new () ; plot.ts (df.tsSeasonalAdjusted) 

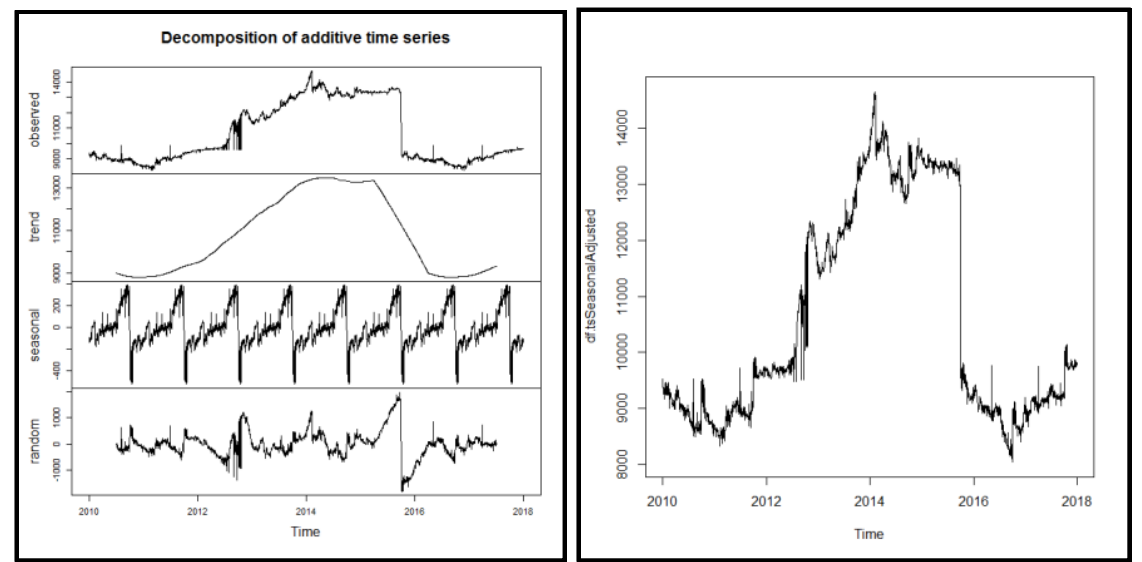

Gambar 12. a. Dekomposisi Data Time Series ; b. Penghilangan Variasi Musiman

Tampak dari ploting gambar 12.a dan 12.b diatas kita tidak lagi membutuhkan data variasi musiman dan lebih membutuhkan data trend untuk melakukan peramala.Perlu dicatat bahwa ts yang disesuaikan tidak menunjukkan banyak penyimpangan/deviasi dari sebelumnya. Hal ini menunjukkan bahwa variasi musiman dalam hal ini minimal. Langkah berikut yang paling penting adalah melakukan peramalan, sejauh ini data historis telah diplot sebagai time series yang sudah disesuaikan untuk variasi musiman. Sekarang kita beralih ke peramalan. Fluktuasi plot time series data $d f$.ts cukup konsisten seiring waktu sehingga peramalan dapat dilakukan dengan menggunakan smoothing eksponensial sederhana, fungsi HoltWinters() pada R yang digunakan untuk smoothing eksponensial sederhana, seperti pada gambar 13 a dan b.

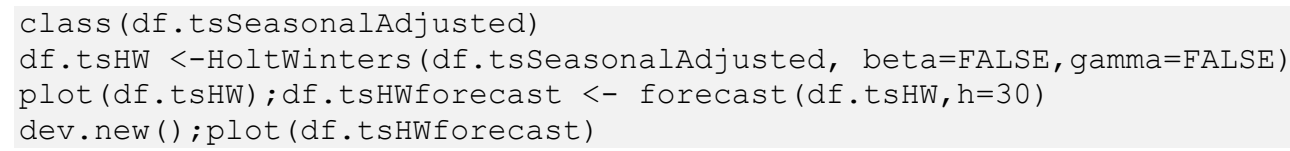

Tampak data setelah difilter dengan dengan HoltWinters (garis merah), lebih halus dari sebelumnya (garis hitam), dan saat dilakukan peramalan hasilnya

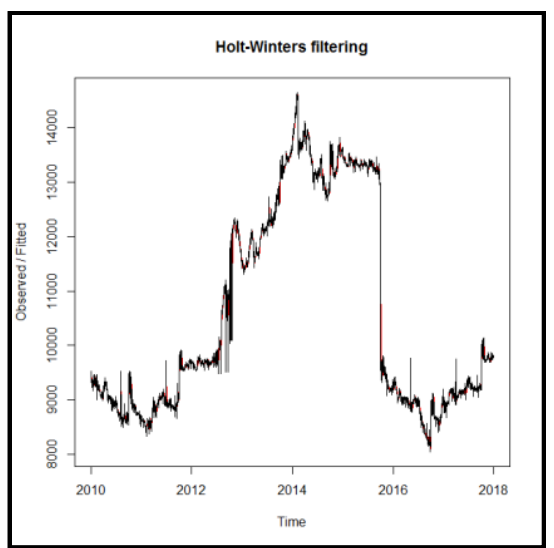

a. Smoothing exponensial data time series

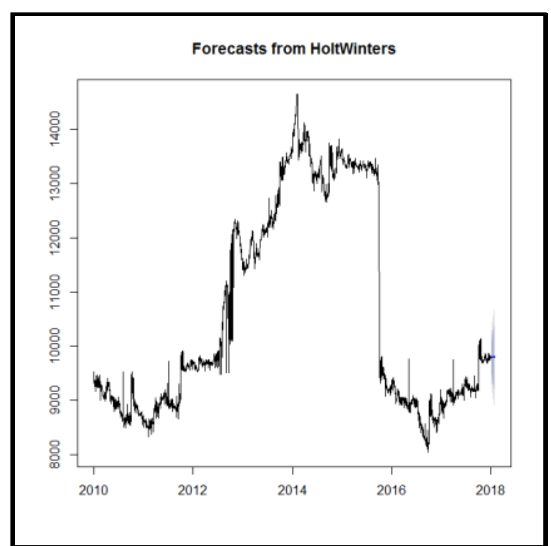

b. Hasil peramalan 30 hari kedepan $(\mathrm{h}=30)$

\section{c. Zoom out hasil peramalan}

\section{Gambar 13. Peramalan Dan Penghalusan Data Kurs 2010-2018}

Gambar 13.c dapat di jelaskan sebagai berikut dengan melihat data angka bahwa interpretasi model peramalan, area abu-abu gelap dalam plot mewakili kisaran nilai tukar df.ts untuk 30 hari ke depan 
dengan prediksi 80\%. Dalam hal ini berada di kisaran 13647.53-13988.07 IDR. Warna abu-abu terang mewakili nilai tukar $d f . t s$ dengan prediksi 90\% yang berada pada kisaran 13617.59 sampai 14138.40 IDR

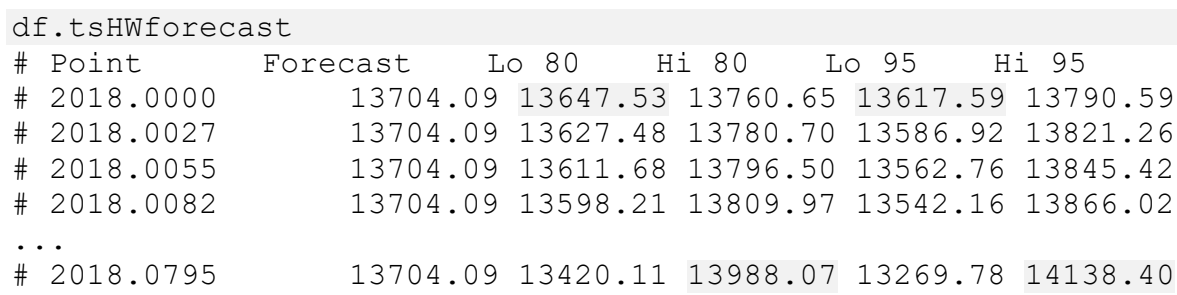

Interpretasi model peramalan, area abu-abu gelap dalam plot mewakili kisaran nilai tukar $d f . t s$ untuk 30 hari ke depan dengan prediksi 80\%. Dalam hal ini berada di kisaran 13647.53-13988.07 IDR. Warna abu-abu terang mewakili nilai tukar $d$ f.ts dengan prediksi $90 \%$ yang berada pada kisaran 13617.59 sampai 14138.40 IDR. Selanjutkan kita akan lakukan validasi peramalan dengan menganalisa Prediction Errors, potongan kode berikut akan melakukan validasi, hitung histogram, lakukan normalisasi residual, tampilkan plot grafiknya. Jika data terdistribusi normal maka, plot menunjukkan kesalahan perkiraan terdistribusi normal dengan rata-rata mendekati 0 . Ini memvalidasi bahwa model peramalan adalah benar-benar cocok dan nilai prediksi cukup akurat, seperti disajikan pada gambar 14 a dan b dibawah ini.

hist (df.tsHWforecast\$residuals, col="yellow")

dnormResiduals

dnorm (df.tsHWforecast\$residuals, mean=mean (as.matrix (df.tsHWforecast\$residuals) , na.rm=TRUE), sd=sd(as.matrix (df.tsHWforecast\$residuals), na.rm=TRUE )) plot (df.tsHWforecast\$residuals, dnormResiduals, col="blue")

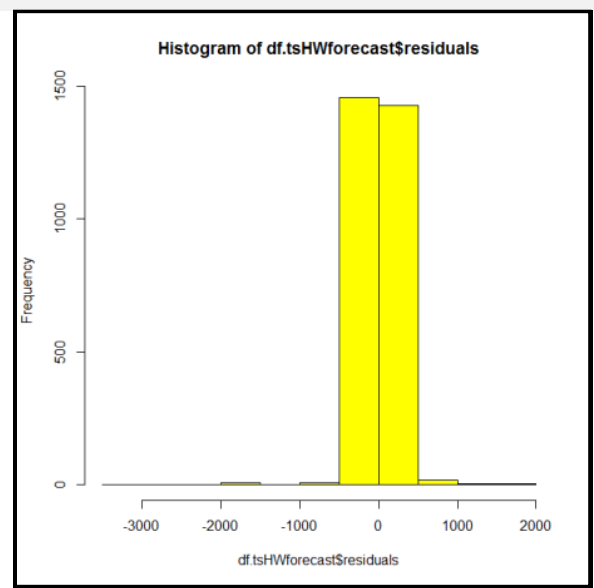

1. Histogram time series

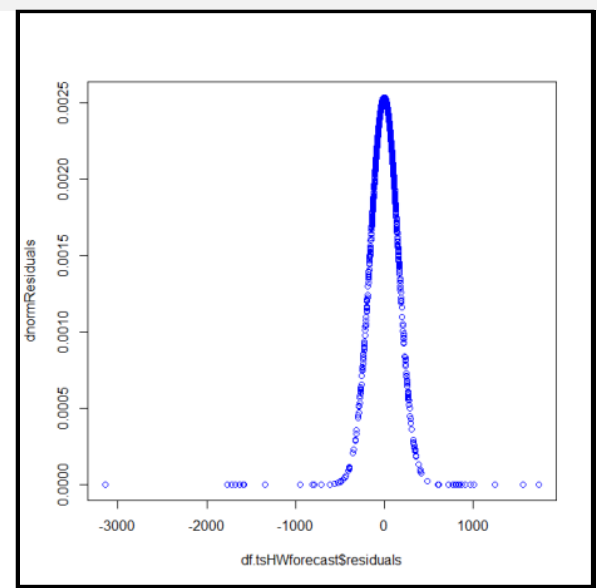

2. Data residual time series

\section{Gambar 14. Validasi Peramalan Data}

Langkah terakhir adaalah evaluasi akurasi hasil peramalan, Akurasi peramalan hanya dapat ditentukan oleh seberapa baik performa model pada data baru yang tidak dipakai saat fitting model. Ukuran data testing biasanya $20 \%$ dari total sampel, jadi kita akan membagi data time series menjadi training set dan test set, seperti kode dan gambar 15 sebagai berikut :

Untuk training gunakan data dari 2016, hari ke 1 hingga 2017 hari ke 150

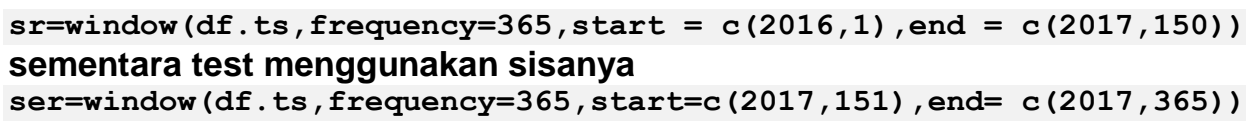

Setelah itu kita lakukan forecasting dengan 4 teknik evaluasi akurasi (Mean, Naïve, Drift dan Seasonal naïve method) 

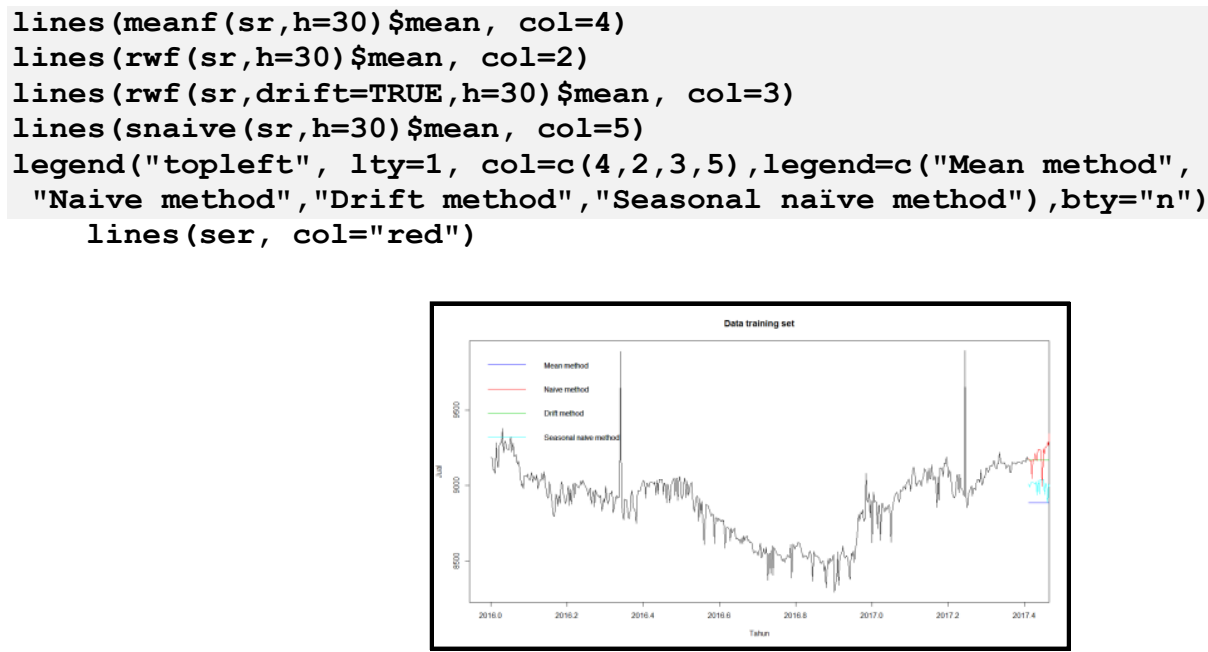

Gambar 15. Validasi Peramalan Data

Akurasi peramalan dari $s r$ (data yang diramalkan data) pada ser (data asli yang dipakai untuk testing dan model terbaik dengan tingkat error terkecil, seperti terlihat dari hasil evaluasi pada table 2 dibawah ini.

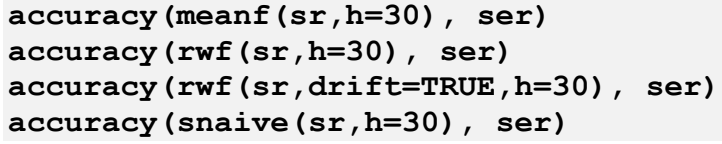

Tabel 2. Evaluasi akurasi data training

\begin{tabular}{rllllll}
\hline Teknik & $\boldsymbol{M E}$ & $\boldsymbol{R M S E}$ & $\boldsymbol{M A E}$ & $\boldsymbol{M P E}$ & $\boldsymbol{M A P E}$ & $\boldsymbol{M A S E}$ \\
\hline mean & $8.115202 \mathrm{e}-14$ & 231.1657 & 186.7288 & -0.06817767 & 2.114142 & 0.9939498 \\
naif & -0.03638132 & 114.0173 & 57.69148 & -0.008219836 & 0.6476601 & 0.3070894 \\
drift & $6.228481 \mathrm{e}-13$ & 114.0173 & 57.69162 & -0.007810046 & 0.64766 & 0.3070902 \\
Seasonal naif & 23.3646 & 243.7740 & 187.8654 & 0.224639 & 2.082259 & 1.000000 \\
\hline
\end{tabular}

Berdasarkan evaluasi akurasi, Nilai ME yang rendah mungkin menyembunyikan ketidakakuratan peramalan karena efek mengimbangi kesalahan perkiraan positif dan negatif yang besar, hal itu terlihat pada teknik naï, sementara teknik lainnya cukup bagus (seasonal naif), Sementara MAE (57.69148) cenderung lebih kecil dari RMSE (114.0173) dan selalu begitu, nilai akurat terbagus diperoleh pada teknik drift. Untuk MPE (0.224639) tidak ditemukan tingkat akurasi yang bagus pada semua teknik yang dipakai kecuali seasonal naif, karena bernilai negative. Nilai MAPE (0.64766) memberikan akurasi yag bagus untuk semua teknik yang dipakai, begitu pula MASE (0.3070902).

\subsection{Aplikasi Peramalan}

Berikut disajikan hasil pembangunan aplikasi berbasis web sebagai implementasi model yang telah di analisis berbasis web yang terdiri dari bagian grafik nilai rupiah, prediksi dan live stock. Tab menu grafik menampilkan grafik kurs harian, mingguan, bulanan dan tahunan seperti tampak pada gambar 16 bagian a.

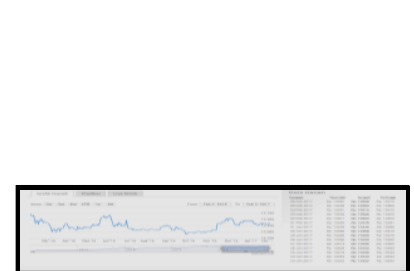

a. Grafik

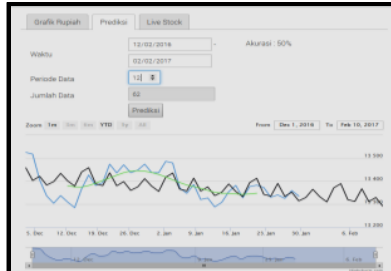

b. Prediksi

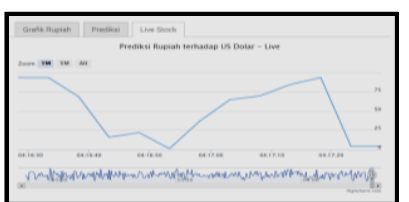

c. Live Stock

Gambar 16. Menu Grafik Rupiah 
Sementara tab Prediksi, merupakan suatu form yang terdiri dari inputan tanggal, periode, jumlah data test dan tombol prediksi, seperti terlihat pada gambar 16.b diatas. Dalam tab ini akan ditampilkan grafik hasil prediksi, dengan legend garis biru muda adalah data asli, hitam hasil prediksi untuk periode $\mathrm{n}$ hari kedepan, hijau hasil smoothing dengan exponesial. Sementara tab live stock hanya menampilkan data berkala tiap menit, seperti disajikan dalam gambar 16.c diatas.

Berdasarkan eksperimen yang dilakukan dengan aplikasi maka dapat di sajikan hasil prediksi pada table 3 yaitu harian sebanyak 14 hari, mingguan sebanyak 32 hari dan bulanan sebanyak 61 hari dibawah ini.

Tabel 3. Hasil eksperimen peramalan harian, mingguan dan bulanan dengan aplikasi

\begin{tabular}{|c|c|c|c|c|}
\hline Tanggal & Asli & CMA & Dekomposisi & Prediksi \\
\hline \multicolumn{5}{|c|}{ Ekperimen harian 14 hari } \\
\hline $01 / 12 / 2016$ & 13582 & 0.00 & 13546.44 & 13574.45 \\
\hline $02 / 12 / 2016$ & 13524 & 0.00 & 13523.92 & 13519.58 \\
\hline 03/12/2016 & 13524 & 13530.25 & 13501.39 & 13489.77 \\
\hline $04 / 12 / 2016$ & 13524 & 13507.13 & 13478.87 & 13477.92 \\
\hline 09/12/2016 & 13337 & 13328.63 & 13366.27 & 13393.92 \\
\hline$\ldots$ & ... & $\ldots$ & $\ldots$ & $\cdots$ \\
\hline $17 / 12 / 2016$ & - & 0.00 & 13186.11 & 13213.38 \\
\hline $18 / 12 / 2016$ & - & 0.00 & 13163.59 & 13159.37 \\
\hline \multicolumn{5}{|c|}{ Eksperiment mingguan 32 hari } \\
\hline $01 / 12 / 2016$ & 13582 & 0.00 & 13423.92 & 13396.52 \\
\hline $02 / 12 / 2016$ & 13524 & 0.00 & 13424.11 & 13388.14 \\
\hline 03/12/2016 & 13524 & 0.00 & 13424.30 & 13429.00 \\
\hline $04 / 12 / 2016$ & 13524 & 13492.00 & 13424.49 & 13438.87 \\
\hline $15 / 12 / 2016$ & 13367 & 13365.75 & 13426.57 & 13431.27 \\
\hline$\ldots$ & $\ldots$ & $\ldots$ & $\ldots$ & $\ldots$ \\
\hline 03/01/2017 & & 0.00 & 13430.17 & 13444.56 \\
\hline $04 / 01 / 2017$ & & 0.00 & 13430.36 & 13459.23 \\
\hline \multicolumn{5}{|c|}{ Eksperimen bulanan 61 hari } \\
\hline $01 / 08 / 2016$ & 13080 & 0.00 & 13160.15 & 13093.27 \\
\hline 02/08/2016 & 13079 & 0.00 & 13159.46 & 13130.79 \\
\hline $03 / 08 / 2016$ & 13114 & 0.00 & 13158.76 & 13139.49 \\
\hline $04 / 08 / 2016$ & 13138 & 0.00 & 13158.06 & 13188.31 \\
\hline$\ldots$ & $\ldots$ & $\ldots$ & $\ldots$ & $\ldots$ \\
\hline 07/10/2016 & & 0.00 & 13113.44 & 13131.16 \\
\hline $08 / 10 / 2016$ & & 0.00 & 13112.74 & 13150.33 \\
\hline
\end{tabular}

\section{KESIMPULAN}

Berdasarkan analisa dan hasil penelitian yang sudah dilakukan diperoleh kesimpulan sementara sebagai berikut :

a. Terbukti hasil analisis dan visualisasi model menunjukan ketepatan pemilihan model peramalan yang sederhana dengan tingkat akurasi yang cukup rendah yang diuji dengan 4 teknik evaluasi dengan menghitung RMSE nilai terbaiknya dengan teknik drift sebesar 114.0173, MAE dengan teknik naif sebesar 57.69148 dan MAPE dengan teknik drift sebesar 0.64766

b. Aplikasi yang dibangun berbasis web telah berhasil menginplementasikan disaian model prediksi yang di pilih yaitu siving average dengan smoothing eksponensial dan perhitungan nilai akurasi seperti disajikan dalam notasi algoritmik. Berdasarkan hasil eksperimen baik harian, mingguan, bulanan diperoleh hasil yang tepat seperti tersaji dalam tabel 


\section{DAFTAR PUSTAKA}

[1] Ekananda, Mahyus. 2004. "Estimasi Persamaan Sistem Non Linear Seemingly Unrelated Regression pada Model Perdagangan Internasional". Jurnal Ekonomi dan Pembangunan Indonesia Vol 4, No 2.

[2] Bergen, Janson Van. 2008. "6 Factors That Influence Exchange". http://www.investopedia.com/articles/basics/04/050704.asp. (Diakses pada tanggal 13 Mei 2017)

[3] Bachtiar, Adella. (2010). Analisis Pergerakan Nilai Tukar Terhadap Neraca Transaksi Berjalan dan Pertumbuhan Ekonomi di Indonesia. Fakultas Ekonomi, Universitas Indonesia.

[4] G. P. Zhang and V. L. Berardi. (2001). Time series forecasting with neural network ensembles: an application for exchange rate prediction.

[5] Emam, Ahmed. (2008). Optimal artificial neural network topology for foreign exchange forecasting. Western Kentucky University.

[6] C’edric Richard, Jos’e Carlos M. Bermudez dan Paul Honeine. (2008). Online prediction of time series data with kernels.

[7] Wahyudi, Adhie Tri. 2008. "Prediksi Nilai Tukar Rupiah terhadap Dolar AS (US\$) pada Kurs Spot dengan Pemanfaatan Artificial Intelligence (AI)”. Surakarta: Universitas Setia Budi Surakarta.

[8] Anwar, Ahmad Awiruddin. 2011. "Prediksi Kurs Rupiah Terhadap Dolar Amerika Menggunakan Metode Fuzzy Time Series”. Semarang: Universitas Diponegoro Semarang.

[9] Ihaka, Ross. (2005). Time Series Analysis : Lecture Notes for 475.726. University of Auckland.

[10] Rahcmawansah, Komet. 2014. “Average-Based Fuzzy Time Series Untuk Peramalan Kurs Valuta Asing (Studi Kasus Pada Nilai Tukar USD-IDR)". Jurusan Matematika, F.MIPA, Universitas Brawijaya.

[11] Amiruddin Anwary, Ahmad. 2011. "Prediksi Kurs Rupiah Terhadap Dollar Amerika Menggunakan Metode Fuzzy Time Series". Skripsi. Semarang: Universitas Diponegoro.

[12] Dwijayanthy dan Naomi. 2009. “Analisis Pengaruh Inflasi, BI Rate, dan Nilai Tukar Mata Uang terhadap Profitabilitas Bank Periode 2003-2007”. Jakarta: Universitas Paramadina Jakarta.

[13] Triyono. (2008). Analisis Perubahan Kurs Rupiah Terhadap Dollar Amerika. Surakarta: Fakultas Ekonomi Universitas Muhammmadiyah Surakarta.

[14] Wibowo dan Saiychu. 2013. "Analisis Pengaruh Suku Bunga, Inflasi, Car, Bopo, Npf Terhadap Profitabilitas Bank Syariah”. Semarang: Jurusan Manajemen Fakultas Ekonomika dan Bisnis Universitas Diponegoro.

[15] Galit Shmueli. (2011). Practical Time Series Forecasting with $R$, University of Maryland, USA and Indian School of Business, India.

[16] Robert H. Shumway, David S. Stoffer.(2017).Time Series Analysis and Its Applications With R Examples, Springer International Publishing

[17] Jonathan D. Cryer, Kung-Sik Chan.(2008).Time Series Analysis With Applications in R, Springer International Publishing.

[18] Tlegenofa. (2015). Forecasting Exchange Rates Using Time Series Analysis: The sample of the currency of Kazakhstan. Singapore.

[19] Kendall, Julie dan Kenneth Kendall, (2011), SYSTEMS ANALYSIS and DESIGN. New Jersey: Pearson Education, Inc 